\title{
Risiko Koalisi Gemuk Dalam Sistem Presidensial Di Indonesia
}

\author{
Idul Rishan \\ Fakultas Hukum Universitas Islam Indonesia \\ JIn. Tamansiswa No. 158 Yogyakarta \\ idul.rishan@uii.ac.id
}

Received: 5 Februari 2020; Accepted: 14 Mei 2020; Published: 25 Agustus 2020

DOI: 10.20885/iustum.vol27.iss2.art1

\begin{abstract}
This study focuses on the risk of a fat coalition in the presidential system in Indonesia. This research aims to obtain three things. First, the reasons for the emergence of fat coalitions in the presidential system. Second, the risks that fat coalitions pose to presidential systems. Third, offer a concept to restore executive and legislative relations. The research method is a doctrinal legal research with a secondary database. The results of the study concluded: first, three things were the reasons for the formation of the fat coalition. 1) The results of amendments to the Constitution that are inconsistent with the strengthening of the presidential system. 2) Due to extreme multiparty system. 3) Due to the weak ideological basis of the party. Second, the risks posed include, among other things, compromise, unstable, and close to authoritarian temptation. Third, this study offers the purification of the presidential system through changes to the Constitution and simplification of political parties.
\end{abstract}

Key Words: Fat coalition; presidential system

\section{Abstrak}

Studi ini difokuskan pada risiko koalisi gemuk dalam sistem presidensial di Indonesia. Riset ini bertujuan untuk memperoleh tiga hal. Pertama, alasan munculnya koalisi gemuk pada sistem presidensial. Kedua, risiko yang ditimbulkan koalisi gemuk pada sistem presidensial. Ketiga, tawaran konsep guna memulihkan relasi eksekutif dan legislatif. Metode riset merupakan penelitian hukum doktriner dengan basis data sekunder. Hasil penelitian menyimpulkan: pertama, tiga hal yang menjadi alasan pembentukan koalisi gemuk. 1) Hasil perubahan Undang-Undang Dasar (UUD) yang tidak konsisten dengan penguatan sistem presidensial. 2) Akibat sistem multipartai ekstrim. 3) Akibat lemahnya basis ideologi kepartaian. Kedua, risiko yang ditimbulkan antara lain pemerintahan bersifat kompromistis, tidak stabil, dan dekat dengan godaan otoriter. Ketiga, studi ini menawarkan pemurnian sistem presidensial melalui perubahan UUD dan penyederhanaan partai politik.

Kata-kata Kunci: Koalisi gemuk; sistem presidensial 


\section{Pendahuluan}

Satu dari lima kesepakatan dasar ${ }^{1}$ perubahan Undang-Undang Dasar Tahun 1945 (UUD 1945) di masa transisi politik (1999-2002) ialah memperkuat sistem presidensial. ${ }^{2}$ Ikhtiar ini dibangun oleh para pelaku perubahan UUD 1945, guna

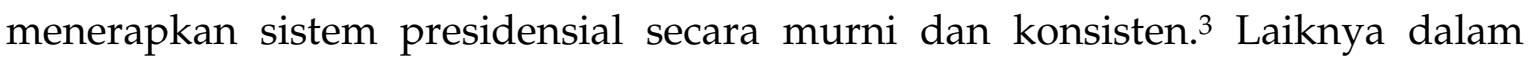
sebuah paham presidensialisme, masing-masing eksekutif dan legislatif memiliki basis legitimasi kekuasaan yang terpisah. Presiden dipilih secara langsung oleh rakyat, demikian halnya anggota parlemen (Dewan Perwakilan Rakyat) yang juga dipilih secara langsung oleh rakyat. ${ }^{4}$ Karakteristik ini menjadi salah satu penanda utama yang mebedakan dengan gaya parlementerianisme. Di dalam sistem ini, relasi eksekutif dan legislatif bersifat interdependen/melebur jadi satu. Pemerintah harus mendapatkan dukungan mayoritas oleh kekuatan partai yang ada di parlemen. Syarat ini dibutuhkan oleh seorang perdana menteri, agar jabatannya tidak mudah dimakzulkan karena alasan politik. ${ }^{5}$

Terlepas dari ragam tesis yang telah ditawarkan oleh para ahli, praktik presidensialisme senyatanya mengalami perkembangan dan tantangan yang cukup dinamis di Indonesia. Selepas transisi politik, salah satu langkah reformatif di bidang percepatan kebutuhan demokrasi ialah diberlakukannya sistem multipartai. Berdasarkan undang-undang partai politik, sistem multi partai diterapkan untuk memutus rantai dominasi kepartaian yang cenderung tunggal

\footnotetext{
${ }^{1}$ Kesepakatan dasar merupakan political agreement antara partai-partai politik dalam melakukan perubahan UUD di tahun 1999-2002. Gelombang demokrasi di banyak negara pasca otoritarian memang lebih banyak ditandai dengan negosiasi dan kompromi. Negosiasi itu kerap dilakukan oleh pertentangan dua kelompok yaitu golongan idealis dan golongan realis. Kaum idealis menginginkan bentuk pemerintahan yang lebih demokratis. Sementara kaum realis merupakan sisa kekuatan rezim lama yang masih aktif dipanggung politik. Lihat Suparman Marzuki, Tragedi Politik Hukum HAM, Pustaka Pelajar- Pusham UII, Yogyakarta, 2011, hlm. 33

2 Beberapa kesepakatan lainnya, seperti (1) tidak mengubah pembukaan UUD (2) mempertahankan Negara Kesatuan Republik Indonesia, (3) meniadakan pasal penjelasan (4) perubahan dilakukan secara addendum. Sebagaimana disarikan oleh Valina Singka Subekti, Menyusun Konstitusi Transisi; Pergulatan Kepentingan dan Pemikiran Dalam Proses Perubahan UUD 1945, Rajawali Pers, Jakarta, 2008, hlm. 85.

${ }^{3}$ Empat substansi perubahan yang memastikan konstitusi hasil amandemen mengarah pada penguatan sistem presidensial. Pertama, pemilihan presiden dan wakil presiden dilakukan secara langsung oleh rakyat. Kedua, pelembagaan masa jabatan presiden dan wapres menjadi bersifat tetap, dalam hal ini selama lima tahun dan maksimal dua periode. Ketiga, pengalihan locus fungsi legislasi dari titik berat sebagai kewenangan Presiden (dengan persetujuan DPR) menjadi otoritas DPR (kendati tetap dibahas bersama dan mendapat persetujuan Presiden). Keempat, likuidasi kedudukan dan peran MPR sebagai lembaga tertinggi negara. Syamsuddin Haris dkk, Ringkasan Eksekutif Position Paper Pemilu Serentak. 2019, Kerja sama Electoral Research Institute- Lembaga Ilmu Pengetahuan Indonesia, Jakarta, 2015, hlm. 2.

4 Scott Mainwaring dan Mathew Shugart, "Juan Lin₹, Presidentialism and Democracy, a Critical Appraisal, Working Papper \#200, July 1993, The Hellen Kellog Institute-International Studies, hlm. 1.

5 Arend Lijhpart, Thinking About Democracy: Power Sharing and Majority Rule in Theory and Practice, Routledge, United State, 2008, hlm. 142.
} 
di bawah kekuatan satu partai seperti partai Golongan Karya (Golkar). Euforia politik ini, di era transisi, telah melahirkan 141 partai politik, yang 48 di antaranya dianggap memenuhi syarat untuk ikut bertarung di ajang Pemilihan Umum (pemilu) tahun 1999.6

Kondisi tersebut tidaklah mudah. Riset Mainwaring memberikan preskripsi bahwa hanya terdapat beberapa negara yang sistem pemerintahannya berjalan stabil di bawah sistem presidensial. Beberapa negara tersebut meliputi Amerika Serikat, Kolombia, Kostarika, Uruguay. Keberhasilan beberapa negara di atas dalam mempraktikan sistem presidensil justru karena di dukung dengan sistem dua partai. ${ }^{7}$ Kombinasi presidensial dengan multi partai yang terfragmentasi dan terpolarisasi kepentingan ideologi dan kepentingan politik menjadi kian konfliktual antara presiden-parlemen, karena keputusan-keputusan publik yang akan dikerjakan presiden cenderung diwarnai oleh kompromi dan akomodasi kepentingan antara partai di parlemen yang berbeda dengan partai presiden. ${ }^{8}$

Berbeda dengan pandangan Mainwaring, Cheibub9 justru menyatakan bahwa presidensialisme dengan multipartai ialah sebuah keniscayaan. Dalam risetnya, koalisi kepartaian tidak bisa hanya dilihat sebagai bagian dari sistem parlementer. Menggabungkan sistem presidensial dengan multipartai merupakan fenomena yang lumrah bahkan sering terjadi. ${ }^{10}$ Dengan presidensialisme multipartai, hubungan presiden dan parlemen akan melahirkan dua pola. Di antaranya yakni dukungan minoritas (presidential minority), dan dukungan mayoritas (presidential majority). Dalam pola koalisi minoritas, kekuatan politik terpecah. Relasi eksekutif-legislatif konfrontatif, bahkan cenderung menghasilkan

\footnotetext{
${ }^{6}$ Denny Indrayana, Amandemen UUD 1945; Antara Mitos dan Pembongkaran, Mizan, Bandung, 2007, hlm. 172.

7 Scott Mainwaring, "Presidentialism, Multipartism, and Democracy: The Difficult Combination", Comparative Political Studies Journal, Vo., 26 No. 2 July 1993, hlm. 204.

8 Agus Riwanto, "Inkompatibilitas Asas Pengaturan Sistem Pemilu dengan Sistem Pemerintahan Presidensial di Indonesia”, Jurnal Hukum Ius Quia Iustum, No. 4 Vol. 21 Oktober 2014, hlm. 516.

9 Pandangan Cheibub diikuti dengan studi Hanan yang menyatakan bahwa koalisi kepartaian dalam presidensialisme multipartai di Indonesia tidak dapat dipersepsikan sebagai sebuah ancaman. Justru dalam dua periode kepemimpinan SBY, sosok Presiden yang akomodatif turut memberikan hasil yang positif, terutama dalam hal stabilitas pemerintahan. Djayadi Hanan, Menakar Presidensialisme Multipartai di Indonesia: Upaya Mencari Format Demokrasi yang Stabil dan Dinamis dalam Konteks Indonesia, Mizan, Bandung, 2014, hlm. 359.

10 Meskipun dalam pendekatan Mainwaring, hanya menyebutkan Chile sebagai negara yang berhasil dengan presidensialisme multipartai. Lihat Jose Antonio Cheibub, Presidentialism, Parlementarianism, and Democracy, Cambridge University Press, New York, 2007, hlm. 68.
} 
pemerintahan yang terbelah (divided government). Sebaliknya, dengan pola koalisi mayoritas, tidak ada pembelahan pemerintahan. Relasi eksekutif-legislatif diasumsikan jauh lebih stabil, karena mayoritas partai politik berada pada koalisi pemerintah. ${ }^{11}$

Kondisi demikian masing-masing pernah dialami oleh rezim pemerintahan Susilo Bambang Yudoyono ${ }^{12}$ dan Joko Widodo ${ }^{13}$. Demi menjamin sekuritas politik, koalisi kepartaian di desain dengan postur yang "gemuk"14 dalam artian kebesaran (oversized coalition). Pada dimensi lain, pelembagaan koalisi gemuk atau mayoritas tentu tidak dapat dilihat sebagai fenomena yang lazim dalam sistem presidensial. Relasi eksekutif-legislatif ${ }^{15}$ yang saling interdependen menyebabkan Presiden memainkan gaya politik akomodatif. Relasi cenderung kompromistis dan tidak menghendaki adanya oposisi di parlemen. Sungguhpun ada, ia tidak akan menjadi kekuatan politik penyeimbang. ${ }^{16}$

Tidak sedikit pengamat memberikan pandangan bahwa koalisi gemuk bisa saja menjadi ancaman dalam sistem presidensial. Tanpa oposisi, politik akan pincang, tidak ada keseimbangan, dan pengawasan. Tanpa kontrol, pemerintahan demokratis bisa kehilangan arah. ${ }^{17}$ Memaksakan koalisi gemuk yang semuanya

${ }^{11}$ Denny Indrayana, Negara antara Ada dan Tiada; Reformasi Hukum Ketatanegaraan, Kompas, Jakarta, 2008, hlm. 215.

12 Di 2004, SBY-JK terpilih sebagai Presiden dari partai demokrat dengan jumlah dukungan 10,5\% (57 kursi). Komposisi ini membuat Presiden berada pada pola "minoritas". Kecenderungan ini membuat Presiden mau tidak mau merangkul sebagian besar dukungan mayoritas partai demi menjamin sekuritas politik. Kondisi ini kembali berulang di 2009 pada saat kepemimpinan periode kedua SBY-Boediono. Presiden kembali merangkul mayoritas partai politik yang ada di parlemen sebagai bagian dari koalisi pemerintahan. Lihat Idul Rishan, "Koalisi-Oposisi”, Kolom Analisis, Harian Kedaulatan Rakyat, 9 Juli 2019, hlm 1.

13 Tidak berbeda dengan SBY, pemerintahan Jokowi pada periode pertama dan periode kedua memperlihatkan gejala yang sama. Meskipun di 2014, pemerintahan Jokowi sempat berada pada pola "minoritas". Dengan dukungan minoritas, Presiden kesulitan membangun program-program pemerintahan. Mau tidak mau Jokowi pada akhirnya merangkul kekuatan partai politik secara mayoritas demi menjaga stabilitas pemerintahan. Tidak jauh berbeda dengan periode kedua, Presiden tampak membangun kekuatan politik mayoritas di parlemen. Termasuk tawarannya kepada Partai Demokrat dan Gerindra. Lihat Idul Rishan, "Amandemen Konstitusi dan Koalisi Partai", Kolom Opini, Tempo, 13 Agustus 2019, hlm. 10.

${ }^{14}$ Koalisi gemuk sebagaimana dimaksud penulis merujuk pada komposisi jumlah partai politik di DPR yang berkoalisi dengan pemerintah (eksekutif). Beberapa ahli menyebut dengan istilah oversized coalition atau majority presidentialism.

${ }_{15}$ Pada hubungan eksekutif-legislatif, penulis membatasi objek riset ini hanya pada konteks hubungan Presiden dan DPR di era Susilo Bambang Yudoyono dan Joko Widodo.

${ }^{16}$ Koalisi kebesaran dengan persilangan kepentingan yang luas seperti ini menyebabkan pemerintah tersandera kepentingan partai-partai. Konsekuensi melibatkan para petinggi partai dalam kabinet akan melahirkan loyalitas ganda (split loyalty). Satu sisi loyalitas kepada presiden, di sisi lain tetap loyal kepada ketua umum partai asalnya. Anies Baswedan dkk, "Menakar Kinerja Satu Tahun Pemerintahan SBY-Boediono", Update Indonesia-Tinjauan Bulanan Ekonomi, Hukum, Keamanan, Politik, dan Sosial, Volume V Nomor 7 November 2010, The Indonesian Institute, hlm. 4.

17 Moch Nurhasim, "Menjadi Oposisi Politik” Opini Harian Kompas 17 Juli 2019, hlm 6. 
bergabung dengan pemenang pemilu, pemerintah akan mudah terperosok ke dalam rezim otoriter ${ }^{18}$ Bahkan tidak ada jaminan bahwa koalisi gemuk akan membuat pemerintahan jauh lebih stabil. Pencapaian prolegnas yang rendah memberikan preposisi akan banyaknya tarik ulur kepentingan partai politik pendukung pemerintah terhadap perencanaan dan arah kebijakan yang dicanangkan pemerintah. ${ }^{19}$ Berangkat dari segala bentuk perdebatan akademik dan penyajian data di atas, tentunya tema ini menjadi cukup relevan untuk dianalisis lebih lanjut dalam skema riset ilmu hukum.

\section{Rumusan Masalah}

Riset ini bertitik tolak pada tiga rumusan masalah. Pertama, mengapa sistem presidensial di Indonesia melahirkan bangunan koalisi gemuk di parlemen?. Kedua, apa saja risiko yang ditimbulkan oleh bangunan koalisi gemuk dalam sistem presidensial?. Ketiga, bagaimana sebaiknya konsep pemulihan relasi eksekutif-legislatif dalam sistem presidensial?.

\section{Tujuan Penelitian}

Fokus tujuan dalam riset ini yaitu untuk menemukan tiga hal sebagai berikut. Pertama, alasan munculnya koalisi gemuk pada sistem presidensial. Kedua, risiko yang ditimbulkan koalisi gemuk pada sistem presidensial. Ketiga, tawaran konsep guna memulihkan relasi eksekutif dan legislatif.

\section{Metode Penelitian}

Studi ini merupakan penilitian hukum doktriner dengan menggunakan pendekatan perundang-undangan dan konseptual. Jenis data yang digunakan adalah data sekunder dan disajikan secara kualitatif.

\footnotetext{
hlm 6 .

19 Tahun pertama pemerintahan (2015) dan tahun terakhir (2019) tidak ada RUU yang disahkan. Tahun 2016 dan 2018 hanya mencapai 3 RUU. Bahkan dari total 6 RUU yang disahkan, 3 RUU berstatus baru dan 3 RUU lainnya merupakan RUU dalam prolegnas 2010-2014. Data ini menunjukan pemerintah tidak punya kebijakan legislasi (state legislative policies) yang jelas dan terukur. Lihat Arya Fernandez, "Risiko Koalisi Gemuk”, Opini Harian Kompas 3 Agustus 2019, hlm 6.
}

18 Zainal Arifin Mochtar, "Koalisi-Oposisi Dalam Sistem Presidensial”, Opini Harian Kompas 10 Juli 2019, 


\section{Hasil Penelitian dan Pembahasan}

\section{Koalisi Gemuk dalam Presidensialisme}

Jika mencermati relasi eksekutif dan legislatif pasca konsolidasi demkorasi, hampir di setiap rezim pemerintahan Presiden cenderung membangun dukungan politik ${ }^{20}$ di DPR. Gejala ini didasarkan atas sebuah asumsi bahwa sekuritas politik di DPR dapat mewujudkan stabilitas pemerintahan. Tentu tidak mudah bagi Presiden, sebab model kepartaian yang terfragmentasi menjadi multipartai ekstrim di DPR, menyebabkan Presiden terpilih cenderung akan membangun koalisi gemuk di DPR. Sebagai contoh di era SBY-JK. SBY membangun koalisi mayoritas guna mencegah pembelahan pemerintahan (divided government).

\section{Tabel 1: Peta Koalisi-Oposisi (SBY-JK)21}

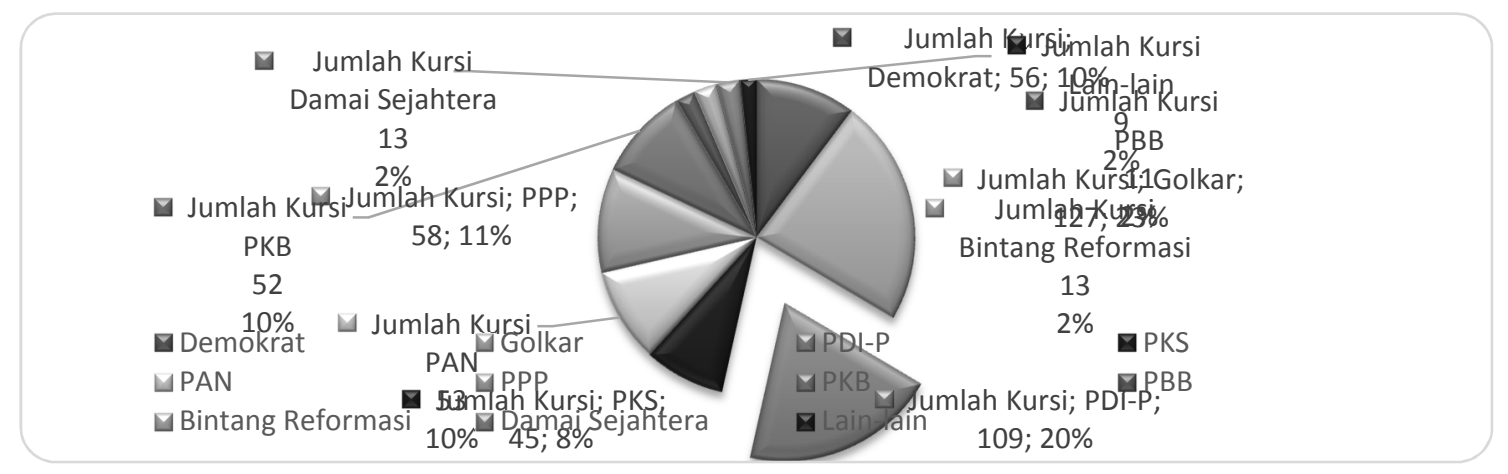

Pasca Pemilu 2004, kekuasaan eksekutif yang terbentuk awalnya berasal dari koalisi yang minoritas di parlemen (minority government). Presiden terpilih, Susilo Bambang Yudhoyono (SBY), berasal dari sebuah partai dengan perolehan suara hanya 7,45 \% yang jika dikonversi ke kursi DPR mendapat 56 kursi atau 10,26\%.22 Merasa tidak stabil, SBY-JK membangun peta koalisi gemuk (majority presidensialism) di DPR. Pada periode pertama kepemimpinannya, hanya Partai Demokrasi Indonesia-Perjuangan (PDI-Perjuangan) yang berperan sebagai partai oposisi. Begitu juga di periode kedua (SBY-Boediono).

20 Dukungan politik sebagaimana dimaksud penulis ialah upaya membangun legitimasi politik di parlemen. Langkah itu di bangun untuk memuluskan kebijakan-kebijakan pemerintah yang harus mendapatkan persetujuan di parlemen (approval by parliament).

${ }^{21}$ Data di olah penulis dengan merujuk Djayadi Hanan, Menakar Presidensialisme Multipartai di Indonesia, Op. Cit., hlm. 29

22 Fitra Arsil, "Stabilitas Sistem Presidensial Indonesia Melalui Pemilihan Umum Serentak dan Presidential Tresshold”, Jurnal Ketatanegaraan, Volume 005 November 2017, hlm. 215. 
Tabel 2: Peta Koalisi-Oposisi (SBY-Boediono) ${ }^{23}$

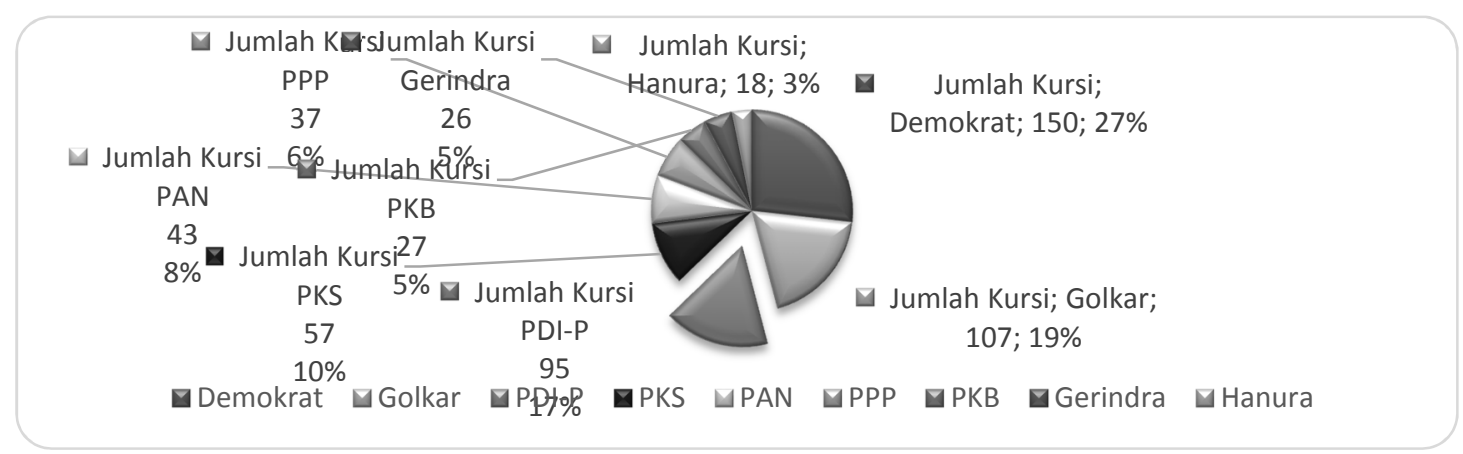

Tidak jauh berbeda dengan periode pertama, di periode kedua, SBYBoediono kembali membentuk koalisi gemuk di DPR. Hanya tiga partai yang berperan sebagai oposisi (PDI-Perjuangan- Partai Gerakan Indonesia Raya (Gerindra) - Partai Hati Nurani Rakyat (Hanura)\}. SBY membangun sekuritas politik hingga 75\% dari partai-partai politik di DPR. Laiknya sebuah preseden, relasi Presiden dan DPR yang diwariskan di era SBY, kemudian diadopsi di era Jokowi. Rezim Jokowi-JK juga membentuk kekuatan koalisi mayoritas. Asumsi awal terus dirawat dan dipertahankan. Bahwa dengan kekuatan koalisi mayoritas, maka penyelenggaraan pemerintahan jauh lebih stabil. Relasi Presiden-DPR di era Jokowi-JK di tabulasikan sebagai berikut.

Tabel 3: Peta Koalisi-Oposisi (Jokowi-JK) 24

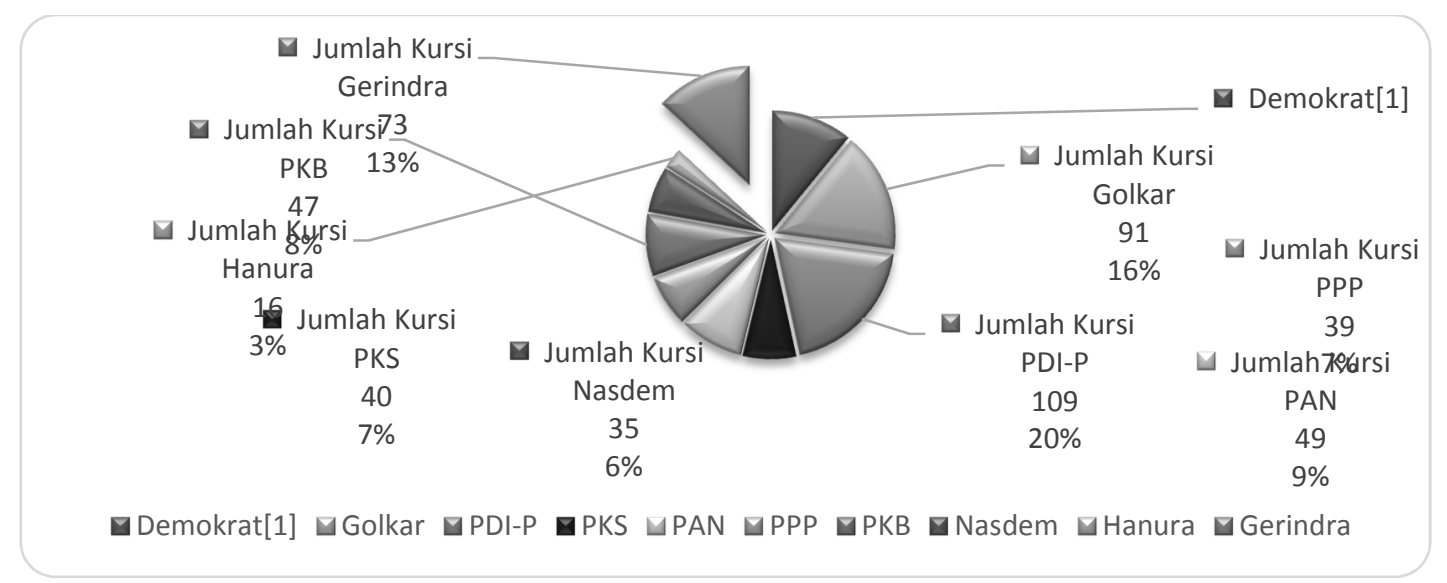

${ }^{23}$ Data di olah penulis dengan merujuk, Djayadi Hanan, Menakar Kinerja Satu Tabun Pemerintahan SBYBoediono, Op. Cit., hlm. 5.

${ }^{24}$ Setelah penetapan KPU Hasil Pemilihan Umum 2014, Partai Demokrat tidak menentukan sikap untuk bergabung pada kelompok koalisi maupun oposisi pada pemerintahan Jokowi-Jusuf Kalla periode 2014-2019. Data diolah kembali dari hasil penelitian Anna Margret dkk, Potret Keterpilihan Anggota Legislatif Hasil Pemilu 2014, Pusat Kajian Politik (Puskapol-Fisip UI) Kerjasama dengan Kementerian Pemberdayaan Perempuan dan Perlindungan Anak Republik Indonesia, Universitas Indonesia, 2014, hlm. 11. 
Data menunjukkan, hanya Partai Keadilan Sejahtera (PKS) dan Gerindra yang berperan sebagai partai oposisi. Sementara Demokrat tidak menentukan sikap baik pada koalisi maupun oposisi. Begitu juga pada periode kedua kepemimpinan Jokowi. Bersama Ma'ruf Amin, Jokowi kembali membangun peta koalisi mayoritas di DPR.

Tabel 4: Peta Koalisi-Oposisi (Jokowi-Ma'ruf) ${ }^{25}$

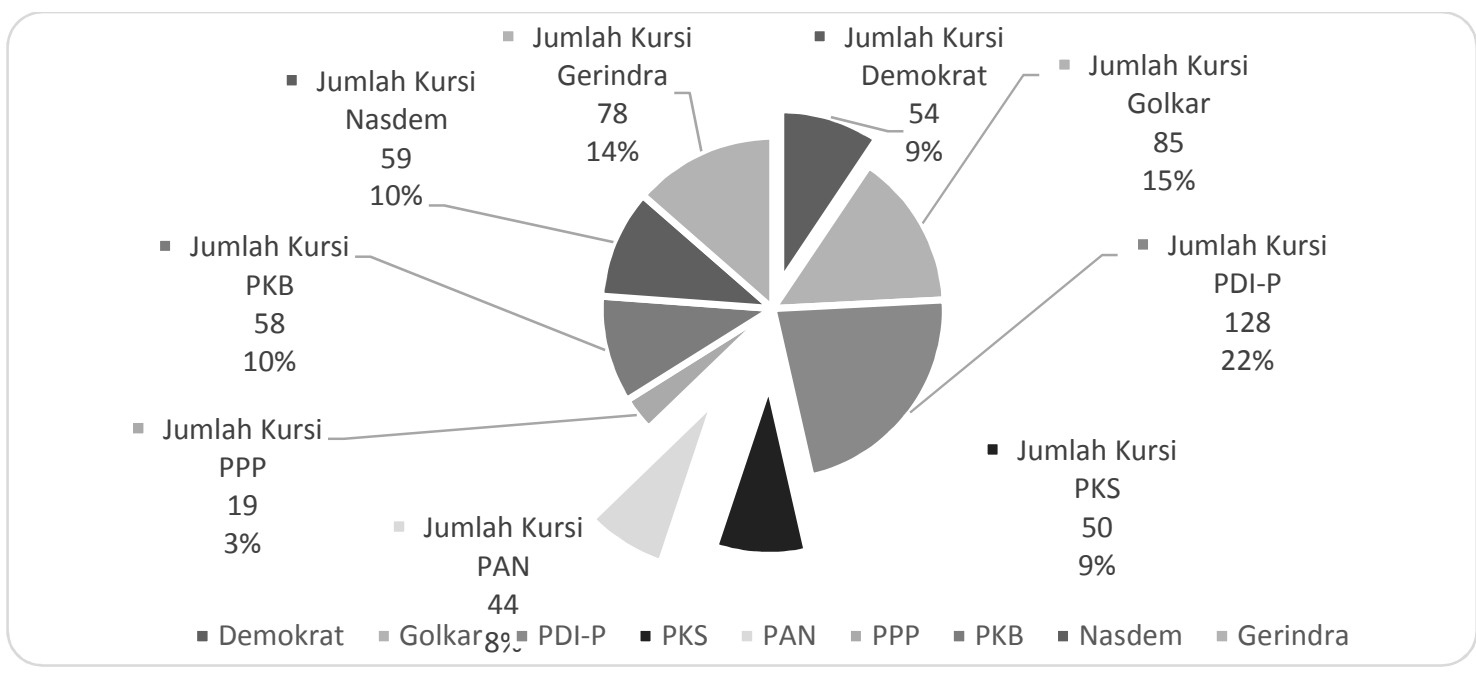

Di periode kedua, Jokowi menarik Gerindra sebagai partai koalisi pemerintah. Partai Amanat Nasional (PAN) dan PKS berperan sebagai oposisi, dan kembali Demokrat ${ }^{26}$ tidak memberikan sikap pada poros koalisi maupun oposisi. Data di atas menunjukkan Jokowi kembali mendapatkan dukungan secara mayoritas di DPR. Data di atas sekaligus mengkonfirmasi bahwa setelah era konsolidasi demokrasi, relasi Presiden dan DPR melebur (blended) menjadi satu. Gejala ini mirip dengan sistem parlementer, yang menempatkan hubungan presiden dan parlemen bercampur satu sama lain (interdepeden relation).

Penulis menemukan tiga faktor yang memengaruhi pelembagaan koalisi mayoritas dalam sistem presidensial. Faktor pertama, disebabkan oleh desain konstitusi. Kesepakatan dasar di era transisi politik untuk menguatkan sistem presidensial, kenyataanya tidak dijalankan secara murni dan konsekuen. Asshiddiqe menilai, sebagai akibat pendulum perubahan dari sistem yang

${ }^{25}$ Data diolah oleh penulis dengan merujuk Komisi Pemilihan Umum Republik Indonesia: Ambang Batas Partai Politik Pemiliban Umum Anggota Dewan Perwakilan Rakyat Yang Memenubi dan Tidak Memenubi Batas Perolehan Suara Sah Nasional Pemiliban Umum Tahun 2019, Sekertariat KPU RI, Jakarta, hlm. 85.

${ }^{26}$ Kecenderungan ke arah koalisi menguat. Meskipun bisa saja sikap lama Partai Demokrat terulang di tahun 2019. Tidak menjadi bagian Koalisi maupun Oposisi. Partai Demokrat belum menentukan sikap koalisioposisi terhadap penyelenggaraan pemerintahan pasca penetapan hasil pemilu 2019. 
sebelumnya memperlihatkan gejala "executive heavy", sekarang sebaliknya timbul gejala "legislative heavy" yang setiap urusan pemerintahan wajib berkaitan dengan fungsi parlemen. ${ }^{27}$

Sebagai contoh dalam fungsi legislasi. Saldi Isra melalui studinya membuktikan bahwa fungsi legislasi setelah perubahan UUD merefleksikan praktik bergaya parlementer. ${ }^{28}$ Disadari atau tidak, pergeseran fungsi legislasi berimplikasi secara luas terhadap fungsi pemerintahan, fungsi DPR itu sendiri, bahkan sampai kepada fungsi kehakiman. Falaakh menguraikan bahwa terdapat empat indikator yang menyebabkan hasil perubahan UUD di era transisi politik meletakkan kekuasaan negara jauh berayun pada kuasa parlemen secara tidak proporsional (legislative heavy). ${ }^{29}$ Pertama dilihat dari sisi atribusi kekuasaan negara yang diterima DPR. ${ }^{30}$ Kedua, sisi perimbangan kekuasaan antar lembaga negara. ${ }^{31}$ Ketiga, sisi perumusan lembaga $\mathrm{DPR}, 32$ dan keempat, sisi praktik ketatanegaraan. ${ }^{33}$

Faktor kedua, terlepas dari segala kelemahan yang dihasilkan melalui desain konstitusi, sistem multipartai turut memengaruhi terbentuknya mayoritas koalisi kepartaian dalam sistem presidensial. Tiga alasan kombinasi sistem presidensial dengan sistem multipartai cenderung problematik. Pertama, sistem presidensial

${ }^{27}$ Jimly Asshiddiqie, Penguatan Sistem Pemerintahan dan Peradilan, Sinar Grafika, Jakarta, 2015, hlm. 60.

${ }^{28}$ Kehadiran Pasal 20 ayat (2) yang mengkonfirmasi konsep fifty-fifty formula dalam fungsi legislasi antara Presiden dan DPR. Frasa "dibahas dan disetujui bersama" hanya dapat dibenarkan dalam sistem pemerintahan parlementer yang tidak memisahkan antara peran pemerintah dan badan legislatif. Dengan demikian purifikasi sistem presidensial tidak terjadi pada fungsi legislasi. Saldi Isra, Pergeseran Fungsi Legislasi: Menguatnya Model Legislasi Parlementer dalam Sistem Presidensial Indonesia, Rajawali Pers, Jakarta, 2010, hlm. 224.

29 Mohammad Fajrul Falaakh, Pertumbuhan dan Model Konstitusi Serta Perubahan UUD 1945 Oleh Presiden, DPR, dan Mabkamah Konstitusi, Gadjah Mada University Press, Yogyakarta, 2014, hlm. 179-182

30 Dari sisi atribusi kekuasaan berdasar konstitusi, terdapat sepuluh klausul di dalam UUD hasil perubahan yang meletakkan kuasa DPR di bidang legislasi. Lihat Pasal 5 ayat (1), (2), Pasal 20 ayat (1-5) dan Pasal 22 ayat (1-3). Lihat juga lima klausul di dalam UUD hasil perubahan yang meletakkan kuasa DPR di sektor pemerintahan. Di antaranya Pasal 11 ayat (1-2), Pasal 13 ayat (2-3) dan Pasal 15. Sementara di bidang yudisial, secara atributif DPR juga diberikan kewenangan untuk terlibat dalam proses pemberian amnesti dan rehabilitasi (Pasal 14 ayat (2)).

31 Hasil perubahan UUD memeberikan power yang berlebih kepada DPR dalam melaksanakan fungsi perimbangan kekuasaaan antar lembaga negara. DPR diletakan sebagai satu-satunya lembaga legislatif yang memiliki fungsi pengawasan antar lembaga negara. Padahal secara kelembagaan, DPR bukanlah satu-satunya lembaga yang merepresentasikan fungsi parlemen. Sebab, secara struktural kekuasaan legislatif terdiri atas DPRDPD dan MPR.

32 Dari sisi perumusan kelembagaan, politik hukum perubahan UUD meletakan DPR sebagai lembaga kuat. Indikasinya terlihat jelas dari bunyi klausul reaktif bahwa "Presiden tidak dapat membekukan dan/membubarkan DPR". Lihat ketentuan Pasal 7C UUDN RI Tahun 1945.

33 Dari sisi praktik ketatanegaraan, kuasa besar DPR juga terpoliferasi pada pengisian jabatan publik melalui fit and propper test baik yang diatur melalui UUD, maupun yang diatur dalam level undang-undang. 
berbasis multipartai cenderung menghasilkan kelumpuhan (imobilitas) akibat kebuntuan (deadlock) eksekutif-legislatif, kebuntuan itu akan berujung pada instabilitas demokrasi. Kedua, sistem multipartai menghasilkan polarisasi ideologis ketimbang sistem dwipartai sehingga seringkali menimbulkan problem komplikasi ketika dipadukan dengan sistem presidensial. Ketiga, kombinasi sistem presidensial dengan sistem multipartai berimplikasi pada kesulitan membangun koalisi antarpartai dalam demokrasi presidensial sehingga berimplikasi pada rusaknya stabilitas demokrasi. ${ }^{34}$

Faktor ketiga. Tidak bisa dimungkiri, lemahnya basis ideologi kepartaian turut serta membentuk mayoritas koalisi kepartaian yang bersifat pragmatis. Lili Romli memetakan dua konsep koalisi kepartaian yang sering dilembagakan dalam sistem pemerintahan.

Tabel 5: Model Koalisi Kepartaian ${ }^{35}$

Policy Blind Coalitions Theory

Menekankan prinsip ukuran atau jumlah

kursi

Minimal winning coalitions (William

Riker)

Asumsi partai bertujuan "office seeking" (memaksimalkan kekuasaan)

Loyalitas peserta koalisi sulit dijamin

Sulit diprediksi, juga range ukuran jumlah partai sangat beragam
Policy Based Coalitions Theory

Menekankan kesamaan dalam preferensi kebijakan

Minimal connected coalitions (Rober Axelrod)

Asumsi partai bertujuan "policy seeking" (mewujudkan kebijakan sesuai kepentingan partai)

Loyalitas peserta koalisi secara minimal diikat oleh kesamaan tujuan kebijakan

Loyalitas peserta koalisi secara minimal diikat oleh kesamaan tujuan kebijakan

Berdasarkan pola di atas, koalisi kepartaian masih dibangun dengan basis blind coalition. Partai-partai bisa berpindah poros dari koalisi ke oposisi secara cepat hanya untuk merawat isu-isu pemerintahan. Model demokrasi yang

34 Scott Mainwaring, "Presidentialism, Multipartism, and Democracy; The Difficult Combination", Comparative Political Studies, Vol. 26, No. 2, 1993, hlm. 198. Pendapat Mainwaring disarikan kembali oleh Sri Yanuarti dan Moch. Nurhasim, "Mencari Sistem Pemilu dan Kepartaian yang memperkuat Sistem Presidensial", Jurnal Penelitian Politik, Volume 10, No. 2 Desember 2013, hlm. 102.

35 Lili Romli, "Koalisi dan Konflik Internal Partai Politik Pada Era Reformasi", Jurnal Politica, Volume 8 Nomor 2 November 2017, hlm. 98. 
mengutamakan ideologi dan basis massa partai tidak lagi jadi panduan. Koalisi berbasis ideologi (ideoligically-connected coalition) hanya sekadar impian. Akhirnya, koalisi tidak didasarkan pada policy-seeking, tapi lebih didasarkan pada perburuan rente (rent-seeking). Batas pemisah pemerintah dan oposisi tidak dipisahkan berdasarkan platform ideologi. Tapi, sekadar apakah mereka duduk dalam kabinet pemerintah (the ins), ataukah berada di luar pemerintahan (the outs). ${ }^{36}$ Pada akhirnya pilihan pada koalisi gemuk atau mayoritas (oversized coalition) menjadi pilihan setiap presiden yang terpilih. Pragmatisme ini yang menjadi pertimbangan elite politik partai yang berkoalisi dengan mengutamakan kepentingan jangka pendek partai mereka. ${ }^{37}$

\section{Risiko Koalisi Gemuk dalam Presidensialisme}

Jika koalisi gemuk (oversized coalition) dilegitimasi sebagai syarat lahirnya stabilitas pemerintahan, kenyataannya tidaklah dapat dibenarkan sepenuhnya. Koalisi gemuk juga melahirkan risiko politik dan problem ketatanegaraan yang tidak sederhana. Ada tiga problem mendasar yang muncul sebagai ekses dari pembentukan koalisi gemuk dalam sistem presidensial. Pertama, pemerintahan cenderung bersifat kompromistis. Akibat meleburnya kekuasaan eksekutif dan legislatif, Presiden menjadi sangat akomodatif terhadap kepentingan-kepentingan partai politik. ${ }^{38}$ Kondisi ini semakin diperparah dengan karakter kepartaian yang masih bersifat rente dan transaksional. Bagi-bagi kursi terhadap jabatan setingkat menteri dilakukan dengan mode "politik dagang sapi". ${ }^{39}$ Di masing-masing periode

\footnotetext{
${ }^{36}$ Lihat Burhanudin Muhtadi, "Plus-Minus Koalisi Obesitas" Opini Media Indonesia, 19 Oktober 2019, hlm. 7. Begitu juga koalisi kepartaian di daerah cenderung asimetris dengan koalisi di tingkat nasional. Misalnya, relasi Partai PDIP-Gerindra berhadap-hadapan dalam politik nasional, tapi bisa berkoalisi mendukung calon yang sama di pilkada Jawa Timur (Jatim) dan Sulawesi Selatan (Sulsel). PDIP dan Demokrat juga cenderung berseberangan di koalisi nasional, namun bisa berkoalisi dalam Pilkada Jateng dan Kalimantan Barat (Kalbar). Begitu juga gambaran relasi PKS dan PDIP yang berseberangan di koalisi nasional tapi mampu membentuk koalisi di Pilkada Jawa Timur (Jatim) dan Sulsel. Relasi ini memberi gambaran bahwa semua bisa berkoalisi dalam satu kepentingan yang sama yaitu office seeking. Lihat Hanta Yuda, "Utak-Atik Koalisi Politik" Opini Media Indonesia, 12 Januari 2018, hlm. 7

${ }^{37}$ Analisis Asrinaldi memetakan pragmatisme partai politik juga dipengaruhi oleh ketentuan ambang batas pencalonan presiden dan wakil presiden sebesar 20\% kursi di DPR atau 25\% suara sah nasional. Lihat Asrinaldi, "Koalisi Model Parlementer dan Dampaknya Pada Penguatan Kelembagaan Sistem Presidensial di Indonesia", Jurnal Penelitian Politik, Volume 10, No. 2 Desember 2013, hlm. 69.

${ }^{38}$ Lihat Hanta Yuda, Presidensialisme Setengah Hati, PT Gramedia Pustaka Utama, Jakarta, 2010, hlm. 68.

39 Politik dagang sapi adalah transaksi politik di ruang tertutup. Praktik dagang sapi merujuk pada pertukaran kepentingan jangka pendek diantara pihak-pihak yang berkoalisi, terutama segelintir elit partai yang tidak berkaitan dengan hajat hidup warga negara atau orang banyak. Lihat Eep Saefulloh Fatah, "Koalisi Tanpa Dagang Sapi”, Kolom Pakar, Media Indonesia, 21 April 2014, hlm. 14.
} 
SBY dan Jokowi, pengisian jabatan setingkat menteri masih saja didominasi antara pertarungan kalangan profesional dan utusan partai politik.

Tabel 6: Perbandingan Komposisi Kabinet SBY dan Jokowi ${ }^{40}$

\begin{tabular}{cccccccc}
\hline \multicolumn{2}{c}{ SBY-JK } & \multicolumn{2}{c}{ SBY-Boediono41 } & \multicolumn{2}{c}{ Jokowi-JK } & \multicolumn{2}{c}{ Jokowi-Ma'ruf $^{2}$} \\
\hline Profesional & Parpol & Profesional & Parpol & Profesional & Parpol & Profesional & Parpol \\
\hline 21 & 16 & 16 & 21 & 18 & 16 & 19 & 15 \\
\hline
\end{tabular}

Secara tidak langsung kondisi tersebut telah mereduksi hak prerogatif42 Presiden dalam menunjuk dan mengangkat pejabat setingkat menteri dalam sistem presidensial. Dengan pola relasi presiden terhadap DPR yang cenderung akomodatif, menyebabkan hubungan DPR terhadap Presiden juga menjadi sangat kompromistis. ${ }^{43}$ Kondisi ini tentu membawa sejumlah ancaman dalam penyelenggaraan pemerintahan. Fungsi pengawasan DPR menjadi lemah dan tidak objektif. Kegagalan beberapa usul hak interpelasi, angket, ataupun menyatakan pendapat DPR pada periode 2004-2009 tidak lepas dari peran lobi yang dilakukan pemerintah kepada parpol koalisi di DPR. Pemerintah melakukan pertemuan tertutup, yang diwakili Wakil Presiden Jusuf Kalla dan beberapa

40 Susilo Bambang Yudhoyono-Jusuf Kalla Kabinet Indonesia Bersatu I (2004-2009) Menteri profesional: 21 orang Menteri parpol: 16 orang (Golkar 2, PKB 2, PBB 2, PKS 3, PAN 2, PPP 2, Demokrat 2, PKPI 1) Susilo Bambang Yudhoyono-Boediono Kabinet Indonesia Bersatu II (2009 2014) profesional:: 16 orang Menteri parpol : 21 orang (2 PAN, 4 Golkar, 6 Demokrat, 4 PKS, 2 PKB, 3 PPP) Joko Widodo-Jusuf Kalla (2014-2019) profesional:: 18 orang Menteri parpol : 16 orang Joko Widodo-Ma'ruf Amin (2019-2024) Menteri profesional:: 19 orang Menteri parpol : 15 orang. Penulis mengolah sumber data dari Harian Nasional Koran Tempo, “Menteri Partai vs Profesional' 15 Agustus 2019. Sebagai pembanding lihat juga Sholehudin Zuhri dkk, "Kekuasaan Partai Simple Majority Dalam Formulasi Kebijakan” International Journal of Government and Social Science, Volume 3 Nomor 2 Tahun 2018, hlm. 104.

41 Awal periode kedua SBY, hak prerogatif benar-benar kehilangan makna dan kewibawaan sebagai salah satu instrument pokok dalam sistem presidensial. Semua itu terjadi karena cara pikir pragmatis yang lebih mengedepankan stabilitas dengan DPR. Lihat Saldi Isra, "Menggadaikan Hak Prerogatif”, Bunga Rampai 10 Tahun Bersama SBY, Kompas, Jakarta, 2014, hlm. 161.

42 Prerogatif secara kebahasaan berasal dari bahasa latin praerogativa (dipllih sebagai yang paling dahulu memberi suara), praerogrativus (diminta sebagai yang pertama memberikan suara), praerogare (diminta sebeium meminta yang lain). Dalam konteks pengangkatan jabatan publik setingkat menteri, Presiden memiliki hak yang bersifat subjektif dalam menunjuk dan mengangkat menteri berdasarkan Pasal 17 UUDN RI tahun 1945. Lihat, Ni'matul Huda, "Hak Prerogatif presiden Dalam Hukum Tata Negara Indonesia" Jurnal Ius Quia Iustum, Nomor 18 Volume 8 Oktober 2001, hlm. 2. Kemudian lihat juga Mei Susanto, "Perkembangan Pemaknaan Hak Prerogatif Presiden”, Jurnal Yudisial, Volume 9 Nomor 3, Desember 2016, hlm. 251.

${ }^{43}$ Dari aspek kebijakan, Relasi kompromistis terhadap DPR juga terbaca melalui sikap Presiden Jokowi terhadap revisi undang-undang KPK. Perubahan UU KPK yang memicu kontroversi meluas dimasyarakat, nyatanya tidak memengaruhi sikap Presiden Jokowi atas revisi undang-undang a quo. Lihat Kurnia Ramadhana, “Masa Tersuram Pemberantasan Korupsi” Opini Harian Koran Tempo, 30 Desember 2019, hlm. 10. 
orang menteri serta pimpinan fraksi-fraksi terkait untuk membicarakan tentang usul interpelasi atau angket yang sedang dibahas di parlemen. ${ }^{44}$

Pada periode 2009-2014. Saat itu hak angket digunakan untuk menyelidiki penyelamatan bailout Bank Century. Meskipun opsi mayoritas parpol menyatakan adanya kebijakan yang salah dalam bailout Century, kenyataannya hasil angket tersebut "gembos" alias nir pasal pemakzulan. 45

Tidak jauh berbeda dengan era SBY, pemerintahan Jokowi mengalami hal yang serupa. Fungsi pengawasan politik DPR tidak berjalan dengan baik. Langkah untuk melakukan interpelasi terhadap kenaikan harga bahan bakar minyak, pengangkatan dan pemberhentian Arcandra Tahar sebagai Menteri Energi Sumber Daya Mineral, justru direduksi dengan kekuatan mayoritas pendukung pemerintah di DPR. Sikap fraksi yang membenarkan semua tindakan pemerintah, tidak lebih dari sebuah pilihan untuk tetap bertahan di jalur kekuasaan. Ironisnya, di era Jokowi satu-satunya hak penyelidikan yang digunakan DPR justru tidak ditujukan pada pemerintah, melainkan pada kinerja KPK. Pansus merekomendasikan perbaikan tata kelola kelembagaan melalui revisi undang-undang KPK.46 Beberapa preposisi di atas telah membenarkan bahwa koalisi gemuk justru mengaburkan peran parlemen dalam fungsi

44 Selain Wapres, Presiden juga mengumpulkan sejumlah menteri yang berasal dari partai koalisi pendukung pemerintah untuk menanyakan kembali loyalitas partainya terhadap kebijakan pemerintah yang tengah diproses di DPR. Kesepakatan yang dihasilkan lobi-lobi tersebut kemudian "diamankan" sebagai keputusan partai yang diinstruksikan untuk ditaati, baik oleh fraksi maupun anggota di DPR. Beberapa angket di era periode pertama pertama SBY, fungsi pengawasan dilakukan secara kompromistis. Beberapa usul angket diantaranya Kenaikan Harga BBM (I); Lelang Gula Impor Ilegal; Kredit Macet Bank Mandiri; Impor Beras; Penunjukan Exxon- Mobil Ltd. sebagai Pimpinan Operator Lapangan Minyak Blok Cepu; Transfer Pricing PT Adaro Indonesia dan Angket Penyelesaian BLBI yang kandas alias prosesnya berhenti di tengah jalan. Lihat, Wawan Ichwanuddin, "Absennya Pengawasan Politik DPR era Reformasi”, Jurnal Penelitian Politik, Volume 9 Nomor 2 Tahun 2012, hlm. 97.

45 Pansus menyusun dua opsi kesimpulan dan rekomendasi, yaitu opsi A, yang menganggap tidak ada kebijakan yang salah dalam proses bailout; dan opsi C, yang menganggap bahwa ada kebijakan yang salah yang menyebabkan terjadinya penyelewengan dalam kasus Century. Setelah voting kesimpulan angket yang ditujukan pada Opsi C dengan 325 suara berbanding 212 suara dengan Opsi A. Meskipun semua fraksi sepakat untuk tidak masuk ke wilayah Pemakzulan. Lihat Mohammad Fajrul Falaakh, "Mosi DPR Nir Ayat Pemakzulan", Bunga Rampai Konsisten Mengawal Konstitusi, Komisi Hukum Nasional, Jakarta, 2014, hlm. 185.

46 Di periode pertama Jokowi, Hak Angket justru hanya digunakan untuk melakukan penyelidikan terhadap kinerja KPK bukan terhadap jajaran pemerintah. Angket ini cukup menyita perhatian publik mengingat untuk pertama kalinya DPR melakukan penyelidikan terhadap komisi negara independen. Lihat Laporan Sidang Paripurna DPR RI, Laporan Panitia Angket DPR RI Tentang Pelaksanaan Tugas dan Wewenang KPK Berdasarkan UU Nomor 30 Tabun 2002 tentang Komisi Pemberantasan Tindak Pidana Korupsi, Sekretariat Dewan Perwakilan Rakyat, 14 Februari 2018, Jakarta, hlm. 2 
pengawasan, termasuk menutup pintu pemakzulan sebagaimana diatur dalam Undang-Undang Dasar Negara Republik Indonesia Tahun 1945 (UUDN RI). ${ }^{47}$

Kedua, bahwa koalisi gemuk tidak sepenuhnya menjamin stabilitas pemerintahan khususnya pada relasi Presiden dan DPR. Dilihat dari aspek fungsi legislasi, dukungan mayoritas berjalan tidak linier dengan jumlah RUU yang disahkan menjadi UU. Data menunjukan koalisi gemuk tidak menjamin pencapaian kinerja legislasi lebih baik.

Tabel 7: Kinerja Legislasi di Era SBY dan Jokowi

\begin{tabular}{|c|c|c|c|c|c|c|c|}
\hline \multicolumn{2}{|c|}{$\begin{array}{c}\text { Legislasi } \\
\text { 2004-200948 }\end{array}$} & \multicolumn{2}{|c|}{$\begin{array}{c}\text { Legislasi } \\
2009-2014^{49}\end{array}$} & \multicolumn{2}{|c|}{$\begin{array}{c}\text { Legislasi } \\
\text { 2014-201950 }\end{array}$} & \multicolumn{2}{|c|}{$\begin{array}{c}\text { Legislasi } \\
\text { 2019-202451 }\end{array}$} \\
\hline Target & 284 RUU & Target & 352 RUU & Target & 189 RUU & Target & 150 RUU \\
\hline Realisasi & $59 \mathrm{UU}$ & Realisasi & $104 \mathrm{UU}$ & Realisasi & 84 UU & Realisasi & - \\
\hline
\end{tabular}

Dengan membaca tabel di atas, presiden terpilih pada dasarnya kesulitan dalam mengontrol sikap partai terhadap program dan kebijakan-kebijakan pemerintah. Dalam koalisi gemuk di parlemen, ada ambivalensi sikap anggota partai politik yang terpolarisasi menjadi dua kepentingan. Anggota partai berusaha untuk tetap sejalan dengan sikap pemerintah, tetapi di sisi lain sikap anggota partai juga wajib memperhatikan kepentingan ketua umum partai politik. Dualisme ini yang menyebabkan koalisi gemuk tidak serta-merta menjamin stabilitas pemerintahan. Dalam 10 tahun masa pemerintahannya, SBY mengakui partai koalisi kenyataannya tidak solid. Bahkan "mereka" lebih keras

${ }^{47}$ Disadari atau tidak, sistem multi partai dan kecenderungan pelembagaan koalisi gemuk di DPR akan menutup terjadinya pemakzulan Presiden dan/ Wakil Presiden. Dukungan mayoritas partai politik menjadi sekuritas jabatan Presiden dan Wakil Presiden dalam menyelenggarakan roda pemerintahan. Lihat ketentuan Pasal 7A dan 7B UUDN RI Tahun 1945.

48 Target itu mengisyaratkan bahwa DPR akan menyelesaikan kurang lebih 50-60 RUU setiap tahun selama masa lima tahun untuk dibahas dan disahkan menjadi undang-undang. Sampai dengan Agustus 2009, RUU dalam kerangka Prolegnas yang telah dibahas dan selanjutnya disahkan menjadi UU berjumlah 59, atau hanya 20,8\% dari total target 284 RUU. Itu berarti kemampuan DPR hanya mencapai hanya 9-11 RUU untuk disahkan menjadi UU setiap tahunnya. Tomy A Legowo, "Menyorot Kinerja Legislasi DPR 2004-2009” Opini, Majalah Parlementaria Masa Bakti Anggota DPR 2004-2009, Edisi Khusus 29 September 2009, Jakarta, hlm. 58.

49 Dari Tahun 2010 sampai 2014, hanya 29,5\% jumlah RUU Prolegnas berhasil diselesaikan menjadi UU. Lihat Majalah Parlementaria Dinamika DPR Periode 2009-2014, Edisi 116 Th. XLIV, 2014, Jakarta, hlm. 17.

50 Data Forum Masyarakat Peduli Parlemen Indonesia (Formappi) menunjukkan, pencapaian legislasi Dewan Perwakilan Rakyat Republik Indonesia (DPR RI) 2014-2019 lebih rendah dibandingkan periode sebelumnya. Tercatat DPR periode 2014-2019 hanya mengesahkan 84 Rancangan Undang-Undang (RUU) dengan komposisi 49 kumulatif terbuka dan 35 program legislasi nasional (Prolegnas). Lihat Rilis Data Forum Masyarakat Peduli Parlemen Indonesia (Formappi), 2019, Kinerja Legislasi DPR 2014-2019.

51 Di periode 2019-2024 target legislasi lebih kecil dari tahun-tahun sebelumnya. Langkah ini dibangun guna mengedepankan kualitas legislasi dibanding aspek kuantitas. Lihat, "Pokok Target Rendah Demi Mutu Legislasi” Politik dan Hukum, Surat Kabar Media Indonesia 11 November 2019, hlm. 4. 
dari oposisi. Model multipartai dengan sistem pemerintahan yang bergaya semiparlementer menyebabkan relasi Presiden dan DPR tidak stabil. ${ }^{52}$

Ketiga, koalisi gemuk bisa menjadi jebakan otoritarian. Akibat mayoritas partai politik di DPR bersekutu dengan pemerintah, Presiden tidak hanya menjadi episentrum kekuasaan eksekutif, tetapi juga menjelma sebagai pengendali kekuatan partai-partai politik yang ada di parlemen. Kecenderungan ini menyebabkan pemerintahan menjadi sangat mudah terperangkap pada rezim otoritarian. Analisis Levitzky dan Ziblatt cukup relevan untuk menggambarkan kondisi tersebut. Bahwa absennya peran legislatif dalam mengawasi eksekutif menjadi sebuah gejala lahirnya pemimpin yang demagog. Demokrasi membusuk dan berjalan mundur. Peran oposisi sebagai watcher melemah akibat tawaran jabatan, bantuan, imbalan, dan bisnis. ${ }^{53}$ Tidak heran jika memasuki awal periode kedua di pemerintahan SBY dan Jokowi, isu penambahan masa jabatan presiden selalu muncul secara reaktif. Peluang untuk melobi ketentuan Pasal 7 UUDN RI memang sangat terbuka. Mengingat Presiden a quo didukung dengan kekuatan mayoritas partai politik yang ada di parlemen. Meleburnya legislatif terhadap eksekutif membuat partai politik enggan untuk berjarak dengan pusaran kekuasaan.

\section{Pemulihan Relasi Eksekutif-Legislatif}

Untuk memulihkan relasi eksekutif dan legislatif, penulis menawarkan dua hal sebagai upaya penguatan sistem presidensial. Pertama, tentu konstitusi akan menjadi peletak dasar untuk menata kembali relasi presiden dan parlemen. Penataan ulang pada level konstitusi dilakukan dalam kerangka memurnikan sistem presidensial. Fungsi legislasi menjadi tawaran pertama guna menegakkan kembali desain sistem presidensial. Pergeseran fungsi legislasi sebagaimana dituliskan oleh Saldi Isra melalui studinya, kenyataannya mendekatkan praktik parlementer dalam sistem pemerintahan. Analisis Saldi juga diperkuat oleh Fajrul Falaakh (sebagaimana diuraikan pada sub bab: Koalisi Gemuk.) yang membuktikan

52 Disarikan sendiri oleh SBY dalam Susilo Bambang Yudoyono, 2014, SBY Selalu Ada Pilihan-Untuk Pencinta Demokrasi dan Para Pemimpin Mendatang, Kompas, Jakarta, hlm. 38.

53 Steven Levitsky dan Daniel Ziblatt, How Democracies Die, Kompas Gramedia, 2018, Jakarta, hlm. 64. 
bahwa pergeseran fungsi legislasi bergerak secara mengerangkai memengaruhi praktik pemerintahan.

Selain pola hubungan Presiden dan DPR, konstitusi juga perlu meletakkan kembali hubungan antara Presiden dan Dewan Perwakilan Daerah (DPD), maupun DPR dan DPD. Penataan itu dilakukan dengan menguatkan peran Dewan Perwakilan Daerah (DPD) sebagai kamar kedua (second chamber). ${ }^{54}$ Mulai dari desain kelembagaan, atribusi kewenangan, dan pola perimbangan kekuasaan antar lembaga negara. Selama ini bandul kekuasaan parlemen terlalu bertumpu pada kekuatan partai politik di DPR. Dari segi kuantitas anggota maupun kualitas kewenangan, DPD tidak mampu memberikan peran sebagai penyeimbang kekuatan partai politik di DPR. Tidak ada kontrol dari kamar kedua sehingga posisi Presiden dipaksa untuk membangun sekuritas politik di DPR guna menjamin stabilitas pemerintahan. Melihat kecenderungan di atas, maka penguatan peran DPD menjadi penting untuk dilakukan.

Setelah menata kembali relasi eksekutif-legislatif pada wilayah konstitusi, hal yang tidak kalah pentingnya ialah menata hubungan presiden dan partai politik pada level undang-undang. Penataan itu tentu difokuskan pada syarat ambang batas pencalonan presiden dan wakil presiden. Perlu dipikirkan kembali relevansi ambang batas pencalonan terhadap penguatan sistem presidensial. Seperti misalnya riset Ghoffar memberikan preposisi bahwa ambang batas pencalonan presiden (presidential tresshold) tidak berpengaruh pada stabilitas relasi presiden dan parlemen. Melalui pendekatan komparasi, Ghoffar membuktikan bahwa presidential tresshold tidak begitu relevan dengan sistem presidensial. Lima negara yang menjadi fokus riset dengan sistem presidensial justru tidak menggunakan syarat ambang batas dalam proses pencalonan presiden dan wakil presiden. 55

54 Pandangan Russel merujuk pendapat Lijhpart, Tsebelis, dan Sartori. Bahwa kamar kedua dapat memberikan peran dalam meminimalisir kekuatan mayoritas partai politik. Meg Russel, "Rethinking Bicameral Strength: A Three- Dimensional Approach" The Journal of Legislative Studies, Volume 19 Issue 3, 27 April 2013, hlm. 370.

${ }_{55}$ Dari lima negara yang menjadi fokus riset ialah Amerika Serikat, Brazil, Meksiko, Peru dan Kolombia. Lihat Abdul Ghoffar, "Problematika Presidential Threshold: Putusan Mahkamah Konstitusi dan Pengalaman di Negara Lain” Jurnal Konstitusi, Volume 15, Nomor 3, September 2018, hlm. 497. 
Kedua, melalui penyederhanaan partai politik. ${ }^{56}$ Ada tiga tawaran yang laik dipertimbangkan guna menciptakan sistem kepartaian ${ }^{57}$ yang relevan dengan sistem presidensial. Tawaran pertama bisa dilakukan dengan penyederhanaan platform atau ideologi. ${ }^{58}$ Ideologi bisa menjadi alat untuk mendorong penyederhanaan partai politik. Setidaknya ada tiga ideologi besar partai politik yang berkembang dalam sistem kepartaian di Indonesia.

Ketiga, ideologi kepartaian tersebut adalah ideologi nasionalis, agama, dan moderat. Dengan merujuk polarisasi ideologi di atas, Syamsudin Haris menawarkan setidaknya akan terdapat 5 partai politik di parlemen dengan klasifikasi partai nasionalis, partai nasionalis moderat, partai moderat, partai agama moderat, dan partai agama. Ideologi kepartaian tersebut dapat mendeskripsikan pola koalisi partai yang akan terbentuk. ${ }^{59}$ Koalisi dengan dasar jarak ideologi yang berdekatan akan cenderung lebih solid dan kokoh dibanding dengan koalisi yang mengandalkan pragmatisme kepentingan politik semata.

Tawaran selanjutnya yang bisa dipertimbangkan ialah dengan merekayasa ambang batas fraksi yang ada di parlemen. Asumsinya tetap mempertahankan model multipartai ekstrim, namun ambang batas fraksi ditentukan sebesar 30\%. Dengan demikian hanya ada dua atau tiga fraksi saja yang terbentuk di parlemen. Konsep koalisi fraksi digagas Jimly Asshidiqie sebagai upaya mempermudah

${ }^{56}$ Empat tipologi partai politik di Indonesia (1) partai politik masyarakat, yaitu partai politik yang baru dibentuk oleh sekelompok warga masyarakat (2) partai politik berbadan hukum, yaitu partai politik bentukan sekelompok warga masyarakat yang memiliki badan hukum resmi karena telah didaftarkan pada institusi yang berwenang (3) partai politik peserta pemilu, yaitu partai berbadan hukum yang memenuhi syarat untuk mengikuti pemilu, dan (4) partai politik parlemen, yaitu partai politik peserta pemilu yang berhasil meraih kursi di parlemen. Fokus penyederhanaan partai politik yang dimaksud oleh penulis ialah partai politik peserta pemilu yang berhasil meraih kursi di parlemen. Lihat Didik Supriyanto dan August Mellaz, Ambang Batas Perwakilan, Perludem, Jakarta, 2011, hlm. 34.

57 Sartori membagi sistem kepartaian menjadi lima bentuk (1) sistem partai tunggal, hanya terdapat satu partai relevan, (2) sistem dua partai, terdapat dua partai relevan, (3) sistem multipartai moderat, terdapat 3-5 partai relevan dan (4) sistem multipartai ekstrim, terdapat lebih dari 5 partai relevan. Setelah era transisi politik di Indonesia, hasil pemilu membentuk sistem multipartai ekstrim. Gejala ini ditandai dengan rata-rata munculnya 89 partai relevan di DPR. Lihat Giovanni Sartori, Parties and Party System: A Frameworks of Analysis, New York: Cambridge Unversty Press, 1976, hlm. 261.

58 Setiap partai politik dibentuk mendasarkan diri pada ideologi yang hendak diusungnya. Ideologi ini yang kemudian menjadi identitas partai. Untuk membedakan antara partai yang satu dengan yang lain dapat dilihat dari ideologi yang dianut oleh partai yang bersangkutan. Lili Romli, "Refomasi Partai Politik dan Sistem Kepartaian di Indonesia”, Jurnal Politica, Volume 2, Nomor 2, November 2011, hlm. 203.

${ }^{59}$ Haris menilai tawaran demikian tidak dapat muncul dalam satu kali pemilu saja. Butuh waktu yang cukup lama untuk dapat mewujudkan sistem kepartaian multi partai sederhana. Setidaknya diperlukan $4-5$ kali pemilu agar dapat tercipta sebuah multi partai sederhana. Lihat Syamsudin Haris, Bawaslu Republik Indonesia, Sistem Kepartaian, Sistem Pemilu dan Sistem Presidensial, Sekretariat Jenderal Bawaslu RI, Jakarta, 2015, hlm. 7. 
pengambilan keputusan di parlemen. ${ }^{60}$ Selain dua tawaran di atas, alternatif lain juga bisa ditempuh dengan merekayasa besaran ambang batas parlemen (parlementary tresshold). Konsep Nurhasim juga relevan untuk dipertimbangkan. Ia menggagas besaran ambang batas dinaikan minimal 5 persen dan maksimal 6,8 persen. ${ }^{61}$ Tujuan utama dalam merekayasa besaran tresshold ialah untuk membentuk sistem multipartai moderat. Dengan demikian hanya ada empat atau lima partai saja yang akan berada di parlemen.

\section{Penutup}

Berdasarkan hasil penelitian dan pembahasan, riset ini menemukan tiga hal. Pertama, pembentukan koalisi gemuk di era SBY dan Jokowi disebabkan oleh beberapa variabel. a) Desain konstitusi hasil perubahan di 1999-2002 kenyataannya tidak sepenuhnya menguatkan sistem presidensial. Asumsi stabilitas pemerintahan masih menjadi pangkal utama penyebab Presiden terpilih membangun sekuritas politik di DPR. b) Sistem kepartaian yang melahirkan multipartai ekstrim turut mempersulit pengambilan keputusan politik di DPR. c) Lemahnya basis ideologi kepartaian menyebabkan koalisi gemuk menjadi sebuah keniscayaan. Kepentingan jangka pendek mendominasi sikap partai untuk berada pada jalur kekuasaan.

Kedua, hasil penelitian menunjukan bahwa koalisi gemuk melahirkan risiko politik yang tidak sederhana. Meleburnya (blended) eksekutif dan legislatif membuat keduanya berada pada relasi yang akomodatif dan kompromistis. Presiden menggadaikan hak prerogatifnya dan Fungsi pengawasan DPR melemah. Bahkan risiko terburuk menyebabkan rezim pemerintahan terjebak godaan otoritarianisme. Begitupun asumsi awal yang menegaskan koalisi gemuk akan mewujudkan stabilitas pemerintahan tidak dapat dijadikan alasan

60 Asshidiqie mengasumsikan konsep demikian jauh lebih tepat untuk mengurai problem sistem kepartaian dan sistem presidensial setelah era reformasi. Meskipun konsep ini juga diakui mengandung kelemahan. Salah satunya kesulitan praktis pimpinan partai politik yang berkoalisi dengan fraksi. Lihat Jimly Asshidiqie, Penguatan Sistem Pemerintahan dan Peradilan, Op. Cit., hlm. 63.

61 Angka tersebut ditentukan dan diambil berdasarkan tiga rumus konversi suara menjadi kursi partai yaitu (1) steady divisor (2) quota, dan (3) divisor seperti D'Hond, Jefferson, Sainte-Laguë, ataukah bentuk modikasinya. Lihat Moh Nurhasim, "Paradoks Pemilu Serentak 2019: Memperkokoh Multipartai Ekstrem di Indonesia" Jurnal Penelitian Politik, Volume 16, No. 2 Desember 2019, hlm. 135. 
pembenar. Dari aspek kinerja legislasi, koalisi gemuk tidak menunjukan pencapaian yang signifikan. Belum lagi sikap partai yang kerap ambivalen.

Ketiga, untuk memulihkan beberapa kondisi di atas, hasil studi memperlihatkan bahwa a) Perubahan konstitusi menjadi peletak dasar untuk menata kembali relasi eksekutif-legislatif (Presiden-DPR-DPD). Penataan dilakukan secara proporsional dalam kerangka memurnikan sistem presidensial. b) Penyederhanaan partai politik menjadi prasyarat utama untuk kembali merapihkan hubungan eksekutif dan legislatif. Penyederhanaan dapat dilakukan dengan beberapa tawaran dan konsekuensi. Langkah tersebut dilakukan untuk membangun sistem kepartaian yang relevan dengan sistem presidensial.

\section{Daftar Pustaka}

\section{Buku}

Asshiddiqie, Jimly, Penguatan Sistem Pemerintahan dan Peradilan, Sinar Grafika, Jakarta, 2015.

Bawaslu Republik Indonesia, Sistem Kepartaian, Sistem Pemilu dan Sistem Presidensial, Sekretariat Jenderal Bawaslu RI, Jakarta, 2015.

Cheibub, Jose Antonio, Presidentialism, Parlementarianism, and Democracy, Cambridge University Press, New York, 2007.

Didik, Supriyanto dan Mellaz August, Ambang Batas Perwakilan, Perludem, Jakarta, 2011.

Falaakh, Mohammad Fajrul, Pertumbuhan dan Model Konstitusi Serta Perubahan UUD 1945 Oleh Presiden, DPR, dan Mahkamah Konstitusi, Gadjah Mada University Press, Yogyakarta, 2014.

_. Bunga Rampai Konsisten Mengawal Konstitusi, Komisi Hukum Nasional, Jakarta, 2014.

Hanan, Djayadi, Djayadi Menakar Presidensialisme Multipartai di Indonesia: Upaya Mencari Format Demokrasi yang Stabil dan Dinamis dalam Konteks Indonesia, Mizan, Bandung, 2014.

Indrayana, Denny, Negara antara Ada dan Tiada; Reformasi Hukum Ketatanegaraan, Kompas, Jakarta, 2008.

Isra, Saldi, Pergeseran Fungsi Legislasi: Menguatnya Model Legislasi Parlementer dalam Sistem Presidensial Indonesia, Rajawali Pers, Jakarta, 2010. Bunga Rampai 10 Tahun Bersama SBY, Kompas, Jakarta, 2014.

Levitsky, Steven dan Ziblatt, Daniel, How Democracies Die, Kompas Gramedia, Jakarta, 2018. 
Lijhpart, Arend, Thinking About Democracy: Power Sharing and Majority Rule in Theory and Practice, Routledge, United State, 2008.

Marzuki, Suparman, Tragedi Politik Hukum HAM, Pustaka Pelajar- Pusham UII, Yogyakarta, 2011.

Sartori, Giovanni, Parties and Party System: A Frameworks of Analysis, New York: Cambridge Unversty Press, 1976.

Singka Valina, Subekti, Menyusun Konstitusi Transisi; Pergulatan Kepentingan dan Pemikiran Dalam Proses Perubahan UUD 1945, Rajawali Pers, Jakarta, 2018.

Yuda, Hanta, Presidensialisme Setengah Hati, PT Gramedia Pustaka Utama, Jakarta, 2010.

Yudoyono, Susilo Bambang, SBY Selalu Ada Pilihan- Untuk Pencinta Demokrasi dan Para Pemimpin Mendatang, Kompas, Jakarta, 2014.

\section{Jurnal}

Arsil, Fitra, "Stabilitas Sistem Presidensial Indonesia Melalui Pemilihan Umum Serentak dan Presidential Tresshold", Jurnal Ketatanegaraan, Volume 005 November 2017.

Asrinaldi, "Koalisi Model Parlementer dan Dampaknya Pada Penguatan Kelembagaan Sistem Presidensial di Indonesia", Jurnal Penelitian Politik, Volume 10, No. 2 Desember 2013.

Ghoffar, Abdul, "Problematika Presidential Threshold: Putusan Mahkamah Konstitusi dan Pengalaman di Negara Lain" Jurnal Konstitusi, Volume 15, Nomor 3, September 2018.

Huda, Ni'matul, "Hak Prerogatif presiden Dalam Hukum Tata Negara Indonesia" Jurnal Ius Quia Iustum, Nomor 18 Volume 8 Oktober 2001.

Ichwanuddin, Wawan, "Absennya Pengawasan Politik DPR era Reformasi", Jurnal Penelitian Politik, Volume 9 Nomor 2 Tahun 2012.

Nurhasim, Moh, "Paradoks Pemilu Serentak 2019: Memperkokoh Multipartai Ekstrem di Indonesia" Jurnal Penelitian Politik, Volume 16, No. 2 Desember 2019.

Mainwaring, Scott, "Presidentialism, Multipartism, and Democracy: The Difficult Combination", Comparative Political Studies Journal, Vol, 26 No.2 July 1993.

Riwanto, Agus, "Inkompatibilitas Asas Pengaturan Sistem Pemilu dengan Sistem Pemerintahan Presidensial di Indonesia", Jurnal Hukum Ius Quia Iustum, No. 4 Vol. 21 Oktober 2014.

Romli, Lili, "Refomasi Partai Politik dan Sistem Kepartaian di Indonesia", Jurnal Politica, Volume 2, Nomor 2, November 2011.

"Koalisi dan Konflik Internal Partai Politik Pada Era Reformasi", Jurnal Politica, Volume 8 Nomor 2 November 2017. 
Russell, Meg, "Rethinking Bicameral Strength: A Three- Dimensional Approach" The Journal of Legislative Studies, Volume 19 Issue 3, 27 April 2013.

Sri Yanuarti, Sri dan Nurhasim, Moh, "Mencari Sistem Pemilu dan Kepartaian yang memperkuat Sistem Presidensial", Jurnal Penelitian Politik, Volume 10, No. 2 Desember 2013.

Susanto, Mei, "Perkembangan Pemaknaan Hak Prerogatif Presiden", Jurnal Yudisial, Volume 9 Nomor 3, Desember 2016.

Zuhri, Sholehudin dkk, "Kekuasaan Partai Simple Majority Dalam Formulasi Kebijakan" International Journal of Government and Social Science, Volume 3 Nomor 2 Tahun 2018.

\section{Penelitian, Makalah \& Artikel}

Arifin Mochtar, Zainal, "Koalisi-Oposisi Dalam Sistem Presidensial", Opini Harian Kompas 10 Juli 2019.

Baswedan, Anies, dkk, "Menakar Kinerja Satu Tahun Pemerintahan SBYBoediono", Update Indonesia-Tinjauan Bulanan Ekonomi, Hukum, Keamanan, Politik, dan Sosial, Volume V Nomor 7 November 2010, The Indonesian Institute.

Fernandez, Arya, “Risiko Koalisi Gemuk”, Opini Harian Kompas 3 Agustus 2019.

Forum Masyarakat Peduli Parlemen Indonesia (Formappi), “Kinerja Legislasi DPR 2014-2019", Jakarta, 2019.

Komisi Pemilihan Umum Republik Indonesia, Ambang Batas Partai Politik Pemilihan Umum Anggota Dewan Perwakilan Rakyat Yang Memenuhi dan Tidak Memenuhi Batas Perolehan Suara Sah Nasional Pemilihan Umum Tahun 2019. Sekertariat KPU RI, Jakarta, 2019.

Koran Tempo, 15 Agustus 2019, "Menteri Partai vs Profesional".

Laporan Sidang Paripurna DPR RI, Laporan Panitia Angket DPR RI Tentang Pelaksanaan Tugas dan Wewenang KPK Berdasarkan UU Nomor 30 Tahun 2002 tentang Komisi Pemberantasan Tindak Pidana Korupsi, Sekretariat Dewan Perwakilan Rakyat, Jakarta, 14 Februari 2018.

Legowo, A. Tomy, “Menyorot Kinerja Legislasi DPR 2004-2009” Opini, Majalah Parlementaria Masa Bakti Anggota DPR 2004- 2009, Jakarta, Edisi Khusus 29 September 2009.

Majalah Parlementaria Dinamika DPR Periode 2009-2014, Edisi 116 Th. XLIV, Jakarta, 2014.

Margret, Anna, dkk, Potret Keterpilihan Anggota Legislatif Hasil Pemilu 2014, Pusat Kajian Politik (Puskapol-Fisip UI) Kerjasama dengan Kementerian Pemberdayaan Perempuan dan Perlindungan Anak Republik Indonesia, Universitas Indonesia. Jakarta, 2014. 
Muhtadi, Burhanudin, "Plus-Minus Koalisi Obesitas" Opini Media Indonesia, 19 Oktober 2019.

Nurhasim, Moch “Menjadi Oposisi Politik” Opini Harian Kompas 17 Juli 2019.

Mainwaring Scott, dan Mathew Shugart, Mathew, "Juan Linz, Presidentialism and Democracy, a Critical Appraisal, Working Papper \#200, July 1993, The Hellen Kellog Institute-International Studies.

Pusat Studi Hukum dan Kebijakan (PSHK), Semua Harus Terwakili: Studi mengenai MPR, DPR, dan Lembaga Kepresidenan, PSHK, Jakarta, 2000.

Ramadhana, Kurnia, "Masa Tersuram Pemberantasan Korupsi" Opini Harian Koran Tempo, 30 Desember 2019.

Rishan, Idul, "Koalisi-Oposisi", Kolom Analisis, Harian Kedaulatan Rakyat, 9 Juli 2019.

"Amandemen Konstitusi dan Koalisi Partai", Kolom Opini, Tempo, 13 Agustus 2019.

Saefulloh Fatah, Eep, “Koalisi Tanpa Dagang Sapi”, Kolom Pakar, Media Indonesia, 21 April 2014.

Surat Kabar Media Indonesia 11 November 2019, Politik Hukum, "Pokok Target Rendah Demi Mutu Legislasi".

Yuda, Hanta, “Utak-Atik Koalisi Politik” Opini Media Indonesia, 12 Januari 2018. 